\title{
Pematangan Demokrasi Melalui Transformasi Demokrasi
}

\author{
Nany Suryawati \\ Universitas Katolik Darma Cendika Surabaya \\ nany.suryawati@ukdc.ac.id. \\ Ika Widiastuti \\ Universitas Krisnadwipayana \\ iwidiastuti86@gmail.com
}

Received: 02 Oktober 2020; Revised: 21 November 2020; Accepted: 28 Desember 2020

DOI: http://dx.doi.org/10.37905/aksara.7.1.137-146.2021

\begin{abstract}
ABSTRAK
Kosakata 'demokrasi' menjadi bagian dari banyak bahasa besar didunia, padahal kata 'demokrasi' berasal dari bahasa Yunani: ' demokratia'; akar maknanya 'demos' yang berarti rakyat; dan 'kratos' yang berarti memerintah. Pada awalnya demokrasi dimaknai sebagai bentuk pemerintahan yang merupakan kebalikan dari bentuk monarkhi dan aristokrasi. Pada susunan masyarakat Yunani, Athena-lah yang memulai dan mngembangkan benih demokrasi modern dengan susunan polis-nya. Polis ini menjadi dasar tumbuhnya demokrasi modern, dan juga masyarakat negara. Para pendukung demokrasi memandang bahwa apa yang baik untuk individu, adalah juga yang baik untuk warga negara. Kedaulatan Rakyat sebagai sumber tertinggi dalam sistem pemerintahan negara, dan pelaksanaan kedaulatan rakyat ini dilakukan secara demokratis, dengan memperhatikan keseimbangan antara perlindungan hukum dan law enforcement (pemaksaan hukum) menjadi hak yang penting, terutama pada saat warga masyarakat berhadapan dengan institusi negara. Constitutional Reform ini mengandung legislation reform dan judicial reform. Legislation reform tidak hanya untuk pengaturan hal-hal baru, tetapi juga penyesuaian dari aturan-aturan yang sudah ada sebelumnya. Hukum yang di reformasi harus dibuat dengan cara aspiratif, lebih menjamin hak-hak rakyat, transparan, sehingga dapat mewujudkan keadilan. Adanya Constitutional Reform ini untuk mematangkan demokrasi yang masih belum menampakkan wujud sebenarnya dalam negara Indonesia yang negara hukum demokratis ini.
\end{abstract}

Kata Kunci : Constitutional Refrom; Judicial Reform, Legislation Reform.

\section{PENDAHULUAN}

Supremasi hukum dapat dimaknai secara sempit, dengan menempatkan hukum pada posisi teratas, untuk menyelesaikan persoalan yang timbul, baik dalam masyarakat maupun dalam konteks politik dan kenegaraan. Di dalam negara hukum demokrasi, persoalan penegakkan hukum hanya merupakan salah satu dari banyak aspek tentang hubungan antara negara, hukum, dan masyarakat. Supremasi hukum ini haruslah dimaknai sebagai supremasi hukum dalam suatu negara hukum demokrasi. Sebuah negara hukum demokrasi mempunyai lima asas normatif yang fundamental, yaitu: ${ }^{1} 1$ ) asas legaliteit; 2) perlindungan hak-hak dasar; 3) asas pengawasan oleh peradilan; 4) pemisahan kekuasaan; 5) demokrasi; sehingga supremasi hukum ditempatkan pada sebuah tatanan negara hukum demokrasi. (Haryono, 2009). 
Kedaulatan rakyat diperkuat dengan adanya perubahan Undang Undang Dasar pada Pasal 1 ayat (2) : "Kedaulatan di tangan rakyat dilaksanakan menurut Undang Undang Dasar", sehingga rumusan baru ini mengandung ide, bahwa kedaulatan di tangan rakyat (asas demokrasi) dan pelaksanaannya diatur dalam Undang Undang Dasar (asas konstitusionalisme), padahal pada rumusan Undang Undang Dasar yang lama, pada Pasal 1 ayat (2) norma hukumnya berisikan ketentuan transformatif atau pengalihan mutlak dari kedaulatan yang semula di tangan rakyat diberikan kepada lembaga negara, yaitu : Majelis Permusyawaratan Rakyat (MPR), inilah yang disebut transformasi demokrasi. Perumusan yang baru, asas konstitusionalisme dalam pelaknasaaan kekuasaan kenegaraan harus dilaksanakan menurut ketentuan hukum karena negara Indonesia adalah negara hukum. Kedaulatan rakyat diterjemahkan sebagai suatu norma hukum, menurut konstitusi, karena berisikan norma-norma kewenangan, yaitu kewenangan kenegaraan. Oleh karena itu, walaupun rakyat merupakan sumber dari kedaulatan, pelaksanaan kedaulatan tersebut harus diatur oleh konstitusi, dan dalam perubahan ini, dapat dibedakan antara kedaulatan yang langsung dilakukan oleh rakyat dan kedaulatan yang dilaksanakan oleh lembaga perwakilan. Memang dalam UUD yang telah mengalami perubahan ini, tidak secara eksplisit dinyatakan sebagai perwujudan dari asas kedaulatan rakyat. Hak dari rakyat dalam menyatakan pendapat dalam suatu pemilihan umum adalah merupakan ciri yang esensial bagi perwujudan adanya pengakuan atas kedaulatan rakyat; sebuah tatanan kenegaraan yang tidak memberikan hak bagi rakyat untuk menyatakan pendapatnya melalui pemilihan umum adalah suatu tatanan politik yang jauh dari nilai demokrasi.

Pelaksanaan kedaulatan rakyat ini tidak lagi diberikan kepada MPR (ketentuan yang lama), akan tetapi dilaksanakan langsung oleh rakyat.

Kedaulatan rakyat yang dilaksanakan langsung oleh rakyat, yaitu :

1. Memilih Presiden dan Wakil Presiden

2. Memilih anggota DPR, DPD dan DPRD;

Presiden/Wakil Presiden dan DPR, DPD, DPRD adalah lembaga perwakilan yang dipilih langsung oleh rakyat, sesuai dengan fungsinya masing-masing yang diatur dalam konstitusi. Salah satu pendekatan untuk memahami demokrasi dan hubungannya dengan pemilihan umum adalah dengan mencermati demokrasi itu dari segi lingkup dan intensitas partisipasi rakyat sebagai warga negara dalam melaksanakan kedaulatannya, karena pemilihan umum sebagai wujud nyata dari demokrasi prosedural, dan pemilihan umum itu sendiri harus dilaksanakan secara demokratis. Semua demokrasi modern melaksanakan pemilihan tetapi tidak semua pemilihan adalah demokratis, karena pemilihan yang demokratis bukan sekedar lambang, tetapi pemilihan yang demokratis harus kompetitif, berkala, berlaku umum (nasional) dan definitif dalam menentukan kepemimpinan dalam pemerintahan. Ukuran suatu pemilihan umum itu demokratis ataukah tidak, adalah:

1. Adanya pengakuan, perlindungan, dan pemenuhan Hak Asasi Manusia (HAM);

2. Terbangunnya kepercayaan masyarakat terhadap pemilihan umum yang menghasilkan pemerintahan yang legitimate;

3. Terdapat persaingan yang adil dari para peserta pemilihan umum, sebagai bukti adanya demokrasi yang kompetitif. 
Demokrasi dan pemilihan umum yang demokratis saling melengkapi, tidak dapat berdiri sendiri-sendiri, karena proses demokrasi harus berdasarkan pada standar dari Hak Asasi Manusia yang meliputi hak rakyat, sebagai pemegang kedaulatan. Melalui perubahan Undang Undang Dasar 1945 menjadi Undang Undang Dasar Negara Republik Indonesia 1945 (UUD NRI 1945), maka peletakan dasar-dasar pemerintahan yang demokratis melalui Konstitusi yang menetapkan pemilihan umum secara berkala setiap lima tahun [Pasal $22 \mathrm{E}$ ayat (1)], dan dilakukan secara langsung, umum, bebas, rahasia, jujur dan adil. Hal ini menunjukkan bahwa Negara Indonesia adalah negara demokratis, yang berusaha mewujudkan demokratisasi dalam tatanan kenegaraan Indonesia.

\section{METODOLOGI}

Kajian ini membahas tentang Pematangan demokrasi di Negara Republik Indonesia dengan menganalisa tatanan ketatanegaraan yang ada dan peraturan perundang-undangan yang berlaku dan penerapannya dalam praktik kettatanegaraan, oleh karean itu metode yang dipergunakan adalah yuridis normatif, dengan mengacu pada dasar negara sebagai staatsfundamentalnorm dan Undang Undang Dasar Negara Republik Indonesia 1945.

\section{PEMBAHASAN}

\section{A. Demokrasi}

Demokrasi adalah bentuk pemerintahan oleh rakyat, hal ini telah didiskusikan secara intensif sejak jaman Yunani Kuno, dan secara terminologi, demokrasi berarti kekuasaan di tangan rakyat, sehingga rakyat lah yang berdaulat, rakyatlah yang berkuasa. Negara Indonesia menganut paham kedaulatan rakyat (democratie), pemilik kekuasaan tertinggi sesungguhnya adalah rakyat, sehingga kekuasaaan itu diselenggarakan bersama rakyat, karena berasal dari rakyat, oleh rakyat, dan untuk rakyat. Melalui sistem konstitusional, yang berdasarkan Undang Undang Dasar, pelaksanaan kedaulatan rakyat disalurkan dan diselenggarakan menurut prosedur konstitusional yang ditetapkan dalam hukum dan Konstitusi (constitutional democracy). Secara sederhana, demokrasi sebenarnya merupakan sebuah mekanisme untuk memimpin negara dalam ranah politik, sebagai suatu mekanisme untuk memilih para pemimpin politik di suatu negara. Metode demokrasi merupakan penataan kelembagaan untuk dapat menghasilkan suatu keputusan politik, melalui mekanisme persaingan (kompetisi) untuk memperebutkan suara terbanyak/posisi sebagai pemenang. Dahulu, demokrasi dilaksanakan secara langsung, karena hal in sangat tepat dan memenuhi makna demokrasi itu sendiri tetapi, pada jaman modern ini, tidak memungkinkan untuk mengumpulkan rakyat dalam jumlah besar, sehingga demokrasi dapat dilaksanakan secara perwakilan, yaitu dengan mewakilkan pada orang-orang tertentu yang telah dipilih rakyat dalam pemilihan umum. Oleh karena itu, timbullah dua macam model demokrasi, yaitu :

a. Demokrasi Langsung; dan

b. Demokrasi Tidak Langsung atau Perwakilan; dan perwakilan ini pada dasarnya adalah lembaga perwakilan dari rakyat, oleh rakyat, dan untuk rakyat.

\section{Demokrasi Modern}

Ada beberapa tipe demokrasi yang dapat disimpulkan, yaitu : 
1. Demokrasi dalam pemerintahan perwakilan rakyat, dengan sistem Presidensiil;

2. Ada pemisahan kekuasaan lembaga secara tegas;

3. Demokrasi dalam pemerintahan perwakilan rakyat yang representatif, ada hubungan antar lembaga legislatif dan eksekutif, dapat saling mempengaruhi; yang di sebut sistem parlementer;

4. Demokrasi dalam sistem perwakilan rakyat yang representatif dan ada pemisahan kekuasaan serta di kontrol langsung oleh rakyat; yang disebut : referendum.

\section{Demokrasi Dalam Negara Hukum}

Kriteria Negara Demokrasi menurut Jimly Asshiddiqie (2014), berdasarkan hasil kesepakatan dalam International Conference Of Jurists tahun 1965 di Bangkok, ditetapkan lima kriteria suatu negara bisa dikatakan sebagai negara demokrasi, yaitu:

1. Supremacy of Law (hukum diatas segala hal), bisa diartikan adanya pengakuan normatif dan empirik akan prinsip supremasi hukum, yaitu bahwa semua masalah diselesaikan dengan hukum sebagai pedoman tertinggi. Dalam perspektif supremasi hukum (supremacy of law), pada hakikatnya pemimpin tertinggi negara yang sesungguhnya, bukanlah manusia, tetapi konstitusi yang mencerminkan hukum yang tertinggi. Pengakuan normatif atas supermasi hukum tercermin dalam perilaku sebagaian terbear masyarakatnya, bahwa hukum itu memang 'supreme'. Bahkan dalam Republik yang menganut sistem Presidensiil yang bersifat murni, konstitusi itulah yang sebenarnya lebih tepat untuk disebut sebagai 'kepala negara'. Itu sebabnya, dalam sistem pemerintahan Presidensiil, tidak dikenal pembedaan anatar Kepala Negara dan Kepala Pemerintahan seperti dalam sistem pemerintahan parlementer.

2. Equality before the law (persamaan di hadapan hukum), prinsip ini sangat jelas di anut oleh Indonesia. Menururt Jimly Asshiddiqie, equality before the law dapat diartikan adanya persamaan kedudukan setiap orang dalam hukum dan pemerintahan, yang diakui secara normatif dan dilaksanakan secara empirik. Dalam rangka prinsip persamaan ini, segala sikap dan tindakan diskriminatif dalam segala bentuk dan manifestasinya diakui sebagai sikap dan tindakan terlarang, kecuali tindakan-tindakan yang bersifat khusus dan sementara yang dinamakan 'affirmatitive actions' guna mendorong dan mempercepat kelompok masyarakat tertentu atau kelompok masyarakat tertentu untuk mengejar kemajuan sehingga mencapai tingkat perkembangan yang sama dan setara dengan kelompok masyarakat kebanyakan yang sudah jauh lebih maju. Kelompok masyarakat tertentu yang dapat diberikan perlakuan khusus melalui 'affirmative actions', yang tidak termasuk pengertian diskriminiasi itu misalnya adalah kelompok masyarakat suku terasing atau kelompok masyarakat hukum adat tertentu yang kondisinya terbelakang. Sedangkan kelompok warga masyarakat tertentu yang dapat diberi perlakuan khusus yang bukan bersifat diskriminatif, misalnya, adalah kaum wanita ataupun anak-anak terlantar.

3. Constitutional Guarantee of human rights (jaminan konstitusional terhadap HAM), adanya perlindungan konstitusional terhadap HAM dengan jaminan hukum bagi tuntutan penegakannya melalui proses yang adil. Perlindungan terhadap HAM tersebut dimasyarakatkan secara luas dalam rangka mempromosikan penghormatan dan perlindungan terhadap HAM sebagai ciri yang penting suatu Negara Hukum yang demokratis. Setiap manusia sejak kelahirannya menyandang hak-hak dan kewajiban- 
kewajiban yang bersifat bebas dan asasi.Terbentuknya negara dan demikian pula penyelenggaraan kekuasaan suatu negara tidak boleh mengurangi arti dan makna kebebasan dan hak asasi kemanusiaan itu. Karena itu, adanya perlindungan dan penghormatan terhadap ahk-hak asasi manusia itu merupakan pilar yang sangat penting dalam setiap negara yang disebut sebagai Negara Hukum. Jika dalam suatu negara, HAM terabaikan atau dilanggar dengan sengaja dan penderitaan yang ditimbulkannya tidak dapat diatasi secara adil, maka negara yang bersangkutan tidak dapat disebut sebagai Negara hukum dalam arti yang sesungguhnya.

4. Impartial Tribune (peradilan yang memihak), adanya peradilan yang bebas dan tidak memihak (independent and impartial judiciary). Peradilan bebas dan tidak memihak ini mutlak harus ada dalam setiap Negara Hukum. Dalam menjalankan tugas judisialnya, hakim tidak boleh dipengaruhioleh siapapun juga, baik karena kepentingan jabatan (politik) maupun kepentingan uang (ekonomi). Untuk menjamin keadilan dan kebenaran, tidak diperkenankan adanya intervensi ke dalam proses pengambilan putusan keadilan oleh hakim, baik intervnsi dari lingkungan kekuasaan eksekutif maupun legislatif ataupun dari kalangan masyarakat dan media massa. Dalam menjalankan tugasnya, hakim tidak boleh memihak kepada siapapun juga kecuali hanya kepada kebenaran dan keadilan. Namun demikian, dalam menjalankan tugasnya, proses pemeriksaan perkara oleh hakim juga harus bersifat terbuka, dan dalam menentukan penilaian dan menjatuhkan putusan, hakim harus menghayati nilainilai keadilan yang hidup di tengah-tengah masyarakat. Hakim tidak hanya bertindak sebagai 'mulut'undang undang atau peraturan perundang-undangan, melainkan juga 'mulut' keadilan yang menyuarakan perasaan keadilan yang hidup ditenag-tengah masyarakat.

5. Civiv Education (Pendidikan Kewarganegaraan); Menurut Zoamroni, yang mengemukakan bahwa pengertian pendidikan kewarganegaraan adalah pendidikan demokrasi yang bertujuan untuk mempersiapkan warag masyarakat berpikir kritis dan bertindak demokratis, melalui aktivitas menanamkan kesadaran kepada generasi baru, bahwa demokratis adalah bentuk kehidupan masyarakat yang paling menjamin hakhak warga masyarakat. Demokrasi adalah suatu learning proses yang tidak dapat begitu saja meniru dari masyarakat lain.Kelangsunagn demokrasi tergantung pada kemampuan mentransformasikan nilai-nilai demokrasi.

Mencermati kriteria negara demokrasi ini, sangat jelas bahwa apabila suatu negara menerapkan sistem demokrasi, maka negara tersebut harus dapat melaksanakan seluruh nilai-nilai demokrasi.

Nilai-nilai demokrasi dapat dijabarkan sebagai berikut:

a. Kebebasan; meliputi tiga hal, yaitu: kebebasan berpendapat, kebebasan berkelompok, dan kebebasan berpartisipasi.

b. Kesetaraan; kesetraaan antar warga merupakan hak yang fundamental, karena diperlukan bagi pengembangan demokrasi, terutama dalam negara yang warga nya heterogen

c. Kedaulatan Rakyat; dalam negara demokratis, kedaulatan ada ditangan rakyat, pemerintahan dari rakyat, oleh rakyat dan untuk rakyat.

d. Kerjasama; pelaksanaan demokratis, memerlukan kerjasama yang baik antar warga masyarakat dan antar kelompok yang ada dalam masyarakat. 
Volume : 07

Nomor : 01

Bulan : Januari

Tahun : 2021

http://ejurnal.pps.ung.ac.id/index.php/AKSARA/index

e. Kepercayaan; kerjasama tidak akan terjadi apabila tdiak ada kepercayaan. Kepercayaan ini merupakan suatu 'modal sosial' yang krusial dalam komunitas masyarakat.

\section{B. DEMOKRASI DI NEGARA REPUBLIK INDONESIA}

Demokrasi Liberal (1945 - 1959)

Partai politik di Indonesia, telah tumbuh sejak jaman kolonial meskipun orientasi perjuangannyabelum mengenai kekuasaan, melainkan sebagai alat perlawanan terhadap bangsa penjajah; setelah merdeka, barulah menjadi perjuangan parpol dan orientasinya adalah kekuasaan. Realitas multipartai yang menjadi landasan perjuangan akan kekuasaan ini kerap disebut sebagai masa demokrasi liberal, yaitu masa kebebasan sebebas-bebasnya khususunya dalm hal politik; kemudian dikacaukan dengan agresi militer Belanda, pada tahun 1947 - 1948, sehingga pusat perhatian bangsa adalah untuk mempertahankan kemerdekaan. Belanda menlakukan disintegrasi terhadap wilayah Negara RI dengan menerapkan sistem federal atau Negara Serikat, dan dipaksa untuk menjadi bagian dari kerajaan Belanda dalam Konferenci Meja Bundar (1949) di Den Haag, akan tetapi status negara Indonesia Serikat hanya bertahan kurang lebih 8 bulan saja, setalh itu Indonesia kembali menjadi Negara Kesatuan

Sebagai negara yang bebas, mandiri dan merdeka, maka aktivitas politik khususnya dalam dunia kepartaian, mulai aktif kembali. Pemilihan Umum tahun 1955 dilakukan dalam 2 tahap pemilihan umum, dilakukan untuk memilih DPR dan Badan Konstituante, yanguntuk DPR diikuti oleh : 36 partai politik, 34 organisasi kemasyarakatan dan 48 perseorangan, sedangkan yang untuk Badan Konstituante diikuti oleh : 39 partai politik, 23 organisasi kemasyakatan dan 29 perseorangan. Pada masa ini tidak ada batasan peserta pemilu, sehingga peserta pemilu diikuti baik partai poltik, orgaisasi kemsayarakatan, maupun perseorangan/independen.

\section{Demokrasi Terpimpin (1959 - 1966) - Era Orde Lama}

Setahun setelah pemilihan umum tahun 1955, dilakukan pelantikan DPR dan Badan Konstituante.Demokrasi Liberal tampak mulai mengacaukan Negara Kesatuan, sehingga Presdien Soekarno mengeluarkan Dekrit Presiden yang fenomenal pada 5 Juli 1959, dan Dekrit inilah yang menjadi dasar dari Demokrasi Terpimpin (democracy with leader Soekarno). Berlakunya kembali UUD 1945, menyebabkan kembalinya sistem pemerintahan khas Indonesia yang 'mirip' presidensiil, dengan berasakan 'gotong royong' yang sesuai dengan jiwa bangsa Indonesia.

Pada era ini, ada tiga porors kekuatan yaitu: Soekarno, Angkatan Darat dan PKI; partai politik mulai 'diredam' agar tidak bertindak sebebas-bebasnya lagi, Sistem multipartai dibatasi dengan keluarnYA Penetapan Presiden No. 7 tahun 1959 tentang syarat-syarat dan penyederhanaan kepartaian, yang diikuti Peraturan Presiden N0 25 tahun 1960, yang memberikan wewenang pada Presiden untuk membubarkan partai politik dengan mendengarkan Mahkamah Konstitusi. masa ini (1960 seharusnya ada pemilihan umum yang ke dua, akan tetapi hingga Soekarno diturunkan, tidak pernah ada pemilihan umum. 
Demokrasi Pancasila (1966 - 1998) - Era Orde Baru

Peristiwa pemberontaka Gerakan 30 September - 01 Oktober 1945, menjadi penentu berakhirnya kekuasaan Soekarno, dengan Surat Perintah Sebelas Maret (Supersemar) tahun 1966, memerintahkan kepada Soeharto untuk menjaga stabilitas dan keamanan negara untuk menjaga kewibawaan Presiden Soekarnodari kekacauan yang ada. Masa ini disebut Masa Orde Baru (Orba), yang pada prinsip nya ingin menjalankan Pancasila dan UUD 1945 secara konsekuen agar tidak seperti yang terjadi pada masa Orde Lama (Orla). Penyehatan sistem kepartaian dilakukan dengan jalan demokratis yaitu melalui pemilihan umum.

Pemilihan Umum yang kedua, tahun 1971, sebagai titik tolak kekuasaan Golongan Karya (Golkar), sebagai pemenang pemilihan umum. Hasil pemilihan umum ini membuka jalan bagi sistem eksekutif yang kuat dengan dukungan partai Gokar, menempatkan Soeharto senagai pemenang sekaligus penguasa 'tunggal'. Pemiliha Umum tahun 1977, dengan dominasi Golkar, terjadi penyederhanaan partai politik, dengan 'menjual' Pancasila untuk melawan segala kritikan, karena kebijakan pemerintah tersebut ( yang memaksa partai-partai politik meleburkan diri), bertentangan dengan demokrasi yang sesungguhnya. Dilanjutkan dengan pemilihan umum 1982, tepat lima tahun setelah pemilihan umum 1977, akan tetapi ambisi Orba semakin menguat, dan untuk melanggengkan kekuasaannya, maka menetapkan Pancasila sebagai ideologi tunggal sehingga berhasil meredam konflik-konflik ideologis, serta digunakan sebagai strategi Orba untuk membangun stabilitas politik nasional. Hasil pemilihan umum 1982 ini tetap memenangkan Golkar, demikian juga hasil pemilihan umum tahun 1987, 1992 dan 1977. Konfigurasi politik Orba berdasarkan kriteria bekerjanya pilar-pilar demokrasi, adalah konfigurasi politik Orla dan Orba adalah sama-sama tidak demkrastis.

Terdapat empat hal (Mahfud MD, 2010) yang membedakan otoriterisme Orba dengan Orla, yaitu: pertama, pada era Orla, tidak ada sistem kepartaian, pada era Orba melahirkan sistem kepartaian yang hegemonik; kedua, tumpuan kekuatan Orla adalah Soekarno sebagai Presiden, pada Orba, tumpuan kekuatan pada Presiden Soeharto, ABRI dan Golkar; ketiga, pada era Orla, terjadi inkonstitusional, pada era Orba, terjadi justifikasi melalui cara konstitusional; dan keempat, obsesi utama Orla, pada pemusatan kekuasaan, sedangkan obsesi Orba pada membangun stabilitas nasional sebagai prasyarat kelancaran pembangunan ekonomi. Akan tetapi gaya kepemimpinan otoriter Soeharto menjadi awal gerakan segenap rakyat untuk bersatu padu melawannya, disebabkan karena kebebasan rakyat yang 'terpasung' oleh Orba. Tepat tanggal 21 Mei 1998, atas desakan rakyat, akhirnya Soeharto mengundurkan diri, dan era barupun dimulai.

\section{Demokrasi Konstitusional (1999 - sekarang) Era Transisi/Reformasi}

Tuntutan paling mendasar reformasi adalah pertama-tama kehidupan berdemokrasi. Diterbitkan undang undang politik yang melipyu UU Pemiliha Umum, UU Partai Politik dan UU Susunan Kedudukan MPR, DPR, DPRD yang disahkan pada awal tahun 1999. Semangat demokratis tampak pada semangat mengekspresikan diri melalui kebebasan berkumpul dan berserikat, sehngga terjadi pergerakan aktif dari partai politik. Terutama pula dasar hukum yang melandasi penyelenggaraan pemilihan umum 1999 sangat membuka ruang bagi partisipasi seluruh elemen masyarakat dalam pemilihan umum. Terdapat empat dasar hukum dalam penyelenggaraan pemilihan umum 1999, yaitu:

1. Tap MPR No. XIV/MPR/1998 tentang Pemilihan Umum; 
Volume : 07

Nomor : 01

Bulan : Januari

Tahun : 2021

http://ejurnal.pps.ung.ac.id/index.php/AKSARA/index

2. UU No. 3 tahun 1999 tentang Pemilihan Umum

3. UU No. 2 tahun 1999 tentang Partai Politik

4. UU No. 4 tahun 1999 tentang Susunan dan Kedudukan MPR, DPR, dan DPRD.

Ke empat landasan ini menetapkan enam (6) asas dalam Pemilihan Umum yaitu: jujur, adil, langsung, umum, bebas dan rahasia. Pemilihan Umum 1999 ini, mrupakan ajang kontestasi yang paling demokratis yang kedua setelah pemilihan umum tahun 1955, karena jumlah partai politik mencapai 48 partai. Pemilihan Umum selanjutnya pada tahun 2004 adalah pemilihan umum yang mengkonkritkan pemahaman tentang demokratisasi yang utuh sebagaimana diatur dalam UUD 1945 hasil amandemen reformasi, dengan demikian pemilihan umum 2004 merupakan pemilihan umum yang berdasarkan pengaturan UUD 1945 yang baru sehingga pemilihan anggota lembaga eksekutif dan legislatif semuanya mengikuti mekanisme pemilihan umum. Pemilihan Umum tahun 2009, yang merupakan pemilihan umum ketiga pada masa reformasi, dan dalam penyelenggaraan pemilihan umum tahun 2014, sangat diharapkan mampu menunjukkan pendewasaan demokrasi serta sikap terpuji para elit politik. Segala kejadian yang menyelimuti pemilu-pemilu pasca reformas, baik itu keberhasilan maupun kegagalannya, harus diapresiasi karena bagaimanapun itu semua adalah dinamika dalam rangka pendewasaan demokrasi.

\section{TRANSFORMASI DEMOKRASI}

Constitutional Reform

Terjadinya perubahan UUD 1945 , justru meletakkan dasar-dasar yang kuat bagi sebuah negara hukum demokrasi. Konstitusi yang merupakan dasar hukum mempunyai fungsi bagi pentaan fungsi-fungsi kenegegaraan, terutama hubungan antar warga masyarakat dengan negara sebagai pemegang kekuasaan. Nilai strategis hasil perubahan UUD 1945 memberikan dasar bagi peletakkan asas negara hukum demkratis, yaitu :

a. perubahan Pasal 1 ayat (1) memberikan penguatan asas konstitusionalisme;

b. penambahan pasal-pasal tentang hak asasi manusia (pasal 28 A s.d. pasal 28J), memperjelas adanya jaminan perlindungan hak-hak dasar dalam konstitusi;

c. dicantumkannya pasal baru yang mengatur tentang pemilihan umum (pasal 22E);

d. dibentuknya lembaga baru: Mahkamah Konstitusi dan Komisi Yudisial yang bertujuan meningkatkan perlindungan terhadap hak-hak konstitusional warga negara.

\section{Legislation Reform}

Legislation Reform diarahkan tidak hanya pada pengaturan hal-hal yang baru, tetapi juga pada penyesuaian terhadap aturan-aturan yang telah ada sebelumnya dengan format reformasi. Hukum yang direformasi harus dibuat dengan cara yang aspiratif, dan lebih memberikan jaminan terhadap hak-hak masyarakat, dan yang terutama lebih transparatif, sehingga lebih dapat menciptakan keadilan. Kewenangan aparat atau lemabag kenegaraan lebih diperjelas mengenai batas dan tanggung jawab dari kewenangan tersebut. Legislation Reform ini lebih mengutamakan niali-nilai keadilan dari dua aspek, baik dari aspek horizontal, maupun dari aspek vertikal. 
Judicial Reform

Lembaga peradilan merupakan benteng terakhir dari upaya penegakan hukum. Kepercayaan masyarakat terhadap lembaga peradilan mengalami penurunan, karena adanya mafia peradilan. Tantangan untuk melakukan judicial reform adalah memposisikan peradilan sebagai lembaga yang berwibawa, karena mandiri dan merdeka dari pengaruh kekuasaan lainnya. Judicial reform ini secara komprehensif, meliputi pelaku utamanya (para hakim) dan proses peradilannya dimulai dari penyidikan, sehingga juga diperlukan adanya integrated justice system, agar supaya tercipta 'fungsionalprofesional'.

\section{PENUTUP}

Negara Hukum yang demokratis, mempunyai mekanisme dalam pelaksanaan kedaulatan rakyat. Kedaulatan rakyat berada ditangan DPR, DPD dan Presiden, dengan dibatasi oleh ketentuan yang tercantum dalam UUD. Dibatasi bukan berarti 'sisa kedaulatan' itu diberikan kepada yang membatasi, akan tetapi kedaulatan itu dipagari oleh prinsip-prinsip hak asasi manusia, dan kemandirian lembaga-lembaga negara yang mampu menjalankan fungsinya masing-masing dengan baik. Hal inilah yang dimaknai dari isi Pasal 1 ayat (2) UUD 1945, yang menyatakan "Kedaulatan berada ditangan rakyat dan dilaksanakan menurut Undang Undang Dasar", mengandung arti dua macam kedaulatan, yaitu: pertama, kedaulatan langsung yang dilakukan rakyat, dan kedua, kedaulatan yang dilakukan oleh badan-badan perwakilan, dan berawal dari pasal inlah terjadi transformasi demokrasi, ketika penerimaan kedaulatan dari rakyat dipagari/dibatasi oleh konstitusi. Inilah yang dimaknai sebagai Negara Hukum, dan konstitusionalisme. Pematangan demokrasi melalui transformasi demokrasi menghasilkan demokrasi yang komprehensif, dengan melibatkan rakyat beserta wakilwakilnya yang berada dalam lembaga legislatif (DPR dan DPD) dan lembaga eksekutif (Presiden).

Diharapkan pematangan demokrasi ini menjadikan Indonesia sebagai Negara Hukum ynag Demokratis sesuai yang dikehendaki rakyat dan telah dituangkan dalam UUD 1945 melalui perubahan sebanyak empat tahap.

\section{DAFTAR BACAAN}

Asshiddiqie, Jimly, 2014, Konstitusi dan Konstitusionalisme Indonesia, Sinar Grafika, Jakarta.

Handayani, Sri dan Fais Yonas Bo'a, 2019, Partai Politik dan Pemilu Dalam Lintasan Sejarah, Pustaka Pelajar, Yogyakarta.

Haryono, 2009, Transformasi Demokrasi, Sekjen dan Kepaniteraan Mahkamah Konstitusi, Jakarta.

Marei, Dominggus, 2018, Penguatan Sistem Demokrasi Untuk Membangun Ekonomi Yang Berkualitas, PT RajaGrafindo, Jakarta.

MD, Mahfud, 2010, Politik Hukum Di Indonesia, PT RajaGrafindo, Jakarta. 
Volume : 07

Nomor : 01

Bulan : Januari

Tahun : 2021

http://ejurnal.pps.ung.ac.id/index.php/AKSARA/index

152 AKSARA: Jurnal IImu Pendidikan Nonformal 